\title{
Productivity of Sunflower Hybrids (Helianthus Annuus L.) Under The Effect of AKM Plant Growth Regulator In The Conditions Low Moisture of Southern Steppe of Ukraine
}

\author{
Oksana Ieremenko, ${ }^{1}$ Valentina Kalitka ${ }^{2}$ \\ ${ }^{I}$ National university of life and environmental sciences of Ukraine \\ ${ }^{2}$ Tavria state agrotechnological university, Ukraine
}

\begin{abstract}
The results of studies on the influence of AKM plant growth regulator $(P G R)$ on growth, development and yield formation of different sunflower hybrids (Zubr, Odes'kyi 249, Forvard, Yason) in low humidity of the southern Steppe of Ukraine are presented. Presowing treatment of seeds of different sunflower hybrids with AKM plant growth regulator causes an increase in leaf surface area by an average of 7\%; increases sunflower plant resistance to abiotic stress and increases productivity by $13-31 \%$.
\end{abstract}

Keywords: growth and development of the plants, hydrothermal conditions, plant growth regulator, productivity, stress resistance, Sunflower.

\section{Introduction}

Sunflower is the leading oilseed crop in Ukraine. Due to low cost of working capital and high liquidity of the product, seed production, even on the level of yield $800 \mathrm{~kg} / \mathrm{ha}$ is considered cost-effective. Its production significantly affects the economic situation in the southern region, where it holds the first place in terms of profitability. According to statistics, in many agribusinesses of southern Ukraine sunflower accounts for $55-75$ $\%$ of the profit from the crop production [1,2].Thus, in recent years sowing area of sunflower in Ukraine increased by several times and exceeds 6 million hectares now. Gross fees due to the expansion of sowing areas and cultivation of new high-performance hybrids provide the needs of oil extraction facilities. Yield potential of hybrids, system of farming, cultivation technology, material, technical provision of the industry and economic mechanisms of formation of the market price of the finished product primarily affect the amount of sunflower production. The first step in sunflower cultivation technology should be the correct choice of a hybrid that best suits the available weather and climate, agro-technical conditions and technical support of a particular enterprise.

State service of Ukraine for the protection of plant variety rights has published a list of varieties and hybrids of sunflower recommended for cultivation in 2015. It has 665 varieties and hybrids, while in 2012 the figure was 417 [3]. Therefore the choice of hybrids that are the most productive in this zone, needs further research.Sunflower hybrids productivity indices are crucial in the formation of yield and depend on their biological characteristics and growing conditions, composed during the growing season. Research in this area confirm that the parameters of individual productivity indicators can be influenced by technological measures, in particular such as terms of sowing, methods of weed control, application of plant growth regulators, etc. $[4,5$, 6]. It should be noted that the formation of reproductive organs of sunflower hybrids such as the size of the inflorescence, weight of 1000 seeds, desquamation level will determine seed yield and quality [7, 8]. These features are individual to new hybrids and in order to maximize the potential productivity one must study them in specific soil and climatic conditions.

Among the natural factors that hinder the increase of sunflower seed production by raising yield in Steppe is insufficient moisture supply of plants as a result of climate aridity. In such circumstances, the crucial importance is selection of drought resistant hybrids and development of moisture-saving farming practices.In recent years, many new sunflower varieties and hybrids that are different from those grown earlier by precociousness, morphological and biological features, high resistance to shading, diseases, lodging, higher yield and product quality, were introduced into production. However, their reaction to methods of adaptive crop production is virtually unknown. Therefore, it is relevant and important for practice to improve one of the elements of cultivation technology (seed treatment plant growth regulators) in the conditions of southern steppe of Ukraine, which was the goal of our work.

\section{Materials and Methods}

\subsection{Materials}

Alkalis, acids, solvents, Mohr's salt and other reagents are purchased at "Himlaborreaktyv" company (Kyiv, Ukraine). 


\subsection{Methods}

Soil preparation: soil sample, which was taken from the experimental plot was air dried. Then all the roots are carefully removed, the ground was rubbed in agate mortar and sieved it through a sieve with $0.25 \mathrm{~mm}$ holes.The humus content in the soil was determined using I.V. Turin method [9], which is based on the oxidation of organic matter of the soil by $0.4 \mathrm{n}$ solution of bichromate of potassium $\left(\mathrm{K}_{2} \mathrm{Cr}_{2} \mathrm{O}_{7}\right)$ till the formation of carbon dioxide. Reaction occurs by the equation:

$$
3 \mathrm{C}+\mathrm{K}_{2} \mathrm{Cr}_{2} \mathrm{O}_{7}+\mathrm{H}_{2} \mathrm{SO}_{4}=2 \mathrm{~K}_{2} \mathrm{SO}_{4}+2 \mathrm{Cr}_{2}\left(\mathrm{SO}_{4}\right)_{3}+8 \mathrm{H}_{2} \mathrm{O}+3 \mathrm{CO}_{2}
$$

Unused for oxidation residue of chromic mixture was titrated by Mohr's salt (double salt) of ammonium sulfate and iron oxide sulphate. By the number of consumed Mohr's salt, residue of chromium compounds was determined, and by the difference between the original amount (idling determination result), and the remainder amount of chromium compounds, which went to the oxidation of humus was determined.

Definition of hydrolyzed nitrogen by Cornfield [10]. The principle of the method is that the soil is hydrolyzed by treating it with alkali. As a result, nitrogen of exchange ammonium, amide, aminosugars, and other compounds is released from the soil in the form of $\mathrm{NH}_{3}$, which is caught by boric acid.

Determination of mobile forms of phosphorus and potassium in the soil using Chirikov method [11]. The method is based on "extraction" of phosphorus and potassium from the soil by 0.5 normal acetic acid at a ratio soil : solution $(1: 25)$ followed by phosphorus determination as molybdenum blue on photoelectric colorimeter, potassium - on flame photometer.

The method of comprehensive lipid extraction (Soxhlet method) is based on highest possible lipid extraction from the analyzed material by repeated treatment with solvent until the lipid content in the material becomes insignificant. Solvent is then distilled off from the resulting extract and the residue containing lipids is dried in conditions that preclude its oxidation, and is weighed [12].

\subsection{Equipment}

In order to receive quantitative indicators during experiments on the definition of soil quality and seeds of sunflower the following equipment was used: analytical scales ANG220 (AXIS, Poland), centrifuge Multifuge (Thermo / Heraeus, Germany), two-channel flame photometer CL22 (Russia), scanning spectrophotometer UV-2800-UNICO (Russia).

\subsection{Soil and climatic conditions of research conduction}

The study was conducted in 2013 - 2015 in Veselovskom district of Zaporizhzhya region and in the laboratory of monitoring of soil and crop products quality of research institute "Agrotechnologies and Ecology" of Tavria state agrotechnological university.Soil of the research sites is southern chernozem with average weighted humus content of $3.4 \%$, easily hydrolyzed nitrogen (by Cornfield) $-91 \mathrm{mg} / \mathrm{kg}$, mobile phosphorus (by Chirikov) - $119 \mathrm{mg} / \mathrm{kg}$ and exchangeable potassium (by Chirikov) $-127 \mathrm{mg} / \mathrm{kg}$ of the soil. The results were compared with established by DSTU standards of indexes of soil fertility for agricultural lands [13].

Soil moisture conditions in the research years differed, both by the rainfall amount, and its uniformity (Table 1). Almost the same amount of precipitation during the growing season was observed in $2013-122 \mathrm{~mm}$ and $2015-155 \mathrm{~mm}$, while in 2014 times more precipitation fell - $233 \mathrm{~mm}$. At the same time, 2013 were distinguished by irregular rainfall, high temperatures and large soil drought during the period from germination to seed maturation. HTC indexes varied within the limits of 0.4-0.8 over the years. Hydrothermal conditions in 2014 compared to 2013 and 2015 were more optimal both by amount and uniformity of rainfall. At the same time, 2014 was characterized by the lowest humidity during flowering of sunflower (36.9\%) compared to 2013 and 2015.

Table 1: Hydrothermal conditions of the growing season of sunflower during research years

\begin{tabular}{|l|l|l|l|}
\hline Indexes & 2013 & 2014 & 2015 \\
\hline Rainfall during the growing season, $\mathrm{mm}$ & 122 & 233 & 155 \\
\hline The sum of active $\left(\right.$ above $\left.+10^{\circ} \mathrm{C}\right)$ temperatures, ${ }^{0} \mathrm{C}$ & 2996 & 2869 & 2756 \\
\hline CHU & 3519 & 3375 & 3225 \\
\hline Hydrothermal coefficient & 0.41 & 0.81 & 0.56 \\
\hline Minimum relative air humidity during flowering, $\%$ & 61.8 & 36.9 & 45.8 \\
\hline
\end{tabular}

(Crop Heat Units - CHU) [14]

\subsection{Scheme of field experiment}

In order to address stated objectives and goal was laid three-factor field experiment was laid, in which factor A are different sunflower hybrids, which provided seed treatment with AKM plant growth regulator [15] - factor B and determination of the effectiveness of its action under hydrothermal conditions of the year of the research - factor $\mathrm{C}$ (Table 2). Seed treatment was carried out $1-2$ days before sowing by incrustation method at the rate of 101 of working solution per 1 ton of seeds. 
Table 2: The scheme of field experiment

\begin{tabular}{|l|l|l|}
\hline Variant & Preparation, consumption rate, 1/t & Concentration of active substance in the working solution, g/l \\
\hline $1(\mathrm{C})$ & Seed treater - Cruiser, 10.0 plus Maxim XL 5.0 & - \\
\hline 2 & $\mathrm{C}+$ AKM, 0.330 & Ionol + dimethyl sulfoxide, 0.015 \\
\hline
\end{tabular}

\subsection{Studied preparation characteristics}

AKM is a film-forming semi-synthetic plant growth regulator of antioxidant action allowed for seed treatment and spraying of grain, oilseed, legume, vegetable crops, and hops. The aqueous solution consists of dimethyl sulfoxide, ionol, PEG-1500 and PEG-400. The consumption rate depends on the crop and level of agricultural background.

\subsection{The technology of sunflower cultivation in the experiment}

The research was conducted on early ripening hybrids of domestic selection: Zubr, Odes'kyi 249, Forvard and Yason [3]. Sunflower seeds were sown early in the third ten-day period of April, the rate of sowing was 55,000 seeds/ha with $70 \mathrm{~cm}$ row spacing. Predecessor - winter wheat. Care of crops, accounting and monitoring of growth and development of plants, yield structure formation of sunflower were carried out according to the "Methodology of field experiments for the study of agronomical sunflower cultivation measures" [16]. Seeds from the inflorescence were taken after drying in the air to determine the mass of 1000 seeds [17, 18]. Mathematical analysis of the results was carried out by Student's test [19] and licensed Agrostat computer program.

\section{Results and Discussion}

Use of pre-sowing seed treatment activates processes of self-regulation and improves germination and resistance to adverse environmental factors [20]. We have determined that incrustation of sunflower seeds by AKM plant growth regulator stimulates germination, certifying by increasing germination vigor by $1.8-5.1$ percentage points (p.p.) relative to the control [8].

Hydrothermal conditions of the year have a significant effect on seed germination (BBCH - 00-09). Thus, due to lack of moisture during sowing in 2013, field germination in all research variants was lower than in 2014 - 2015 (Table 3). When applying AKM plant growth regulator for pre-sowing treatment of seeds of sunflower hybrids, field germination increased in all variants. However, in 2013 the difference between control and research variants ranged between 2.2 - 8.9 percentage points, while in 2014 - 2015 - 0.7 - 3.6 percentage points for all the studied hybrids. The increase in the difference between the sowing properties of seeds of control and research variants in a stress year (2013) shows anti-stress (antioxidant) properties of AKM growth regulator. This is confirmed by research of scientists such as purse V. Kalitka, Z. Zolotukhina, L. Pokoptseva $[21,22]$.

Table 3: Vegetative sunflower plant productivity, depending on pre-sowing seed treatment by AKM growth regulator and hydrothermal conditions of the year

\begin{tabular}{|c|c|c|c|c|c|c|c|c|c|c|}
\hline \multirow[t]{4}{*}{ Indices } & \multirow{4}{*}{$\begin{array}{l}\text { Year } \\
\text { (factor C) }\end{array}$} & \multicolumn{8}{|c|}{ Hybrid (factor A) } & \multirow{4}{*}{\begin{tabular}{|l}
$\mathrm{LSD}_{05}$ \\
$\mathrm{~A}$ \\
$\mathrm{~B}$ \\
$\mathrm{C}$
\end{tabular}} \\
\hline & & Zubr & & Odes & 249 & Forvard & & Yaso & & \\
\hline & & \multicolumn{8}{|c|}{ PGR (factor B) } & \\
\hline & & $\begin{array}{l}\text { no } \\
\text { PGR } \\
\end{array}$ & AKM & $\begin{array}{l}\text { no } \\
\text { PGR } \\
\end{array}$ & AKM & $\begin{array}{l}\text { no } \\
\text { PGR }\end{array}$ & AKM & $\begin{array}{l}\text { no } \\
\text { PGR }\end{array}$ & AKM & \\
\hline \multirow{3}{*}{$\begin{array}{l}\text { Field germination, } \\
\%\end{array}$} & 2013 & 61.4 & 66.2 & 73.7 & 75.9 & 69.4 & 78.3 & 66.5 & 73.9 & \multirow{3}{*}{$\begin{array}{l}1.1 \\
1.1 \\
0.9\end{array}$} \\
\hline & 2014 & 78.3 & 80.7 & 77.6 & 78.3 & 76.4 & 79.9 & 80.1 & 83.7 & \\
\hline & 2015 & 79.1 & 81.4 & 77.8 & 80.9 & 75.7 & 79.3 & 81.4 & 84.6 & \\
\hline \multirow{3}{*}{$\begin{array}{l}\text { Plant height, } \\
\text { m }\end{array}$} & 2013 & 1.76 & 1.80 & 1.24 & 1.57 & 1.75 & 1.80 & 1.69 & 1.79 & \multirow{3}{*}{$\begin{array}{l}0.11 \\
0.16 \\
0.09\end{array}$} \\
\hline & 2014 & 1.77 & 1.81 & 1.48 & 1.70 & 1.79 & 1.83 & 1.70 & 1.80 & \\
\hline & 2015 & 1.80 & 1.83 & 1.53 & 1.69 & 1.81 & 1.86 & 1.74 & 1.81 & \\
\hline \multirow{3}{*}{$\begin{array}{l}\text { stem diameter, } \\
\mathrm{cm}\end{array}$} & 2013 & 2.6 & 2.8 & 2.2 & 2.4 & 2.5 & 2.9 & 2.7 & 2.8 & \multirow{3}{*}{$\begin{array}{l}0.1 \\
0.1 \\
0.2\end{array}$} \\
\hline & 2014 & 2.7 & 2.9 & 2.2 & 2.5 & 2.7 & 2.9 & 2.8 & 2.8 & \\
\hline & 2015 & 2.8 & 2.9 & 2.4 & 2.5 & 2.7 & 2.9 & 2.8 & 2.9 & \\
\hline \multirow{3}{*}{$\begin{array}{l}\text { Amount of leaves, } \\
\text { units per plant }\end{array}$} & 2013 & 24.2 & 26.7 & 19.6 & 21.1 & 20.4 & 23.3 & 20.9 & 22.1 & \multirow{3}{*}{$\begin{array}{l}0.6 \\
0.5 \\
0.7\end{array}$} \\
\hline & 2014 & 26.8 & 28.2 & 21.4 & 24.4 & 23.9 & 24.2 & 22.1 & 23.4 & \\
\hline & 2015 & 27.3 & 28.5 & 22.7 & 24.9 & 23.6 & 25.0 & 22.7 & 23.1 & \\
\hline \multirow{3}{*}{$\begin{array}{l}\text { eaf surface area, } \\
\text { thousand } \mathrm{m}^{2} / \mathrm{ha}\end{array}$} & 2013 & 16.6 & 18.4 & 20.8 & 22.2 & 18.9 & 21.6 & 19.1 & 20.2 & \multirow{3}{*}{$\begin{array}{l}0.9 \\
0.6 \\
1.1\end{array}$} \\
\hline & 2014 & 19.8 & 22.7 & 25.3 & 24.6 & 25.2 & 26.7 & 26.4 & 28.7 & \\
\hline & 2015 & 23.1 & 25.3 & 28.2 & 28.4 & 29.0 & 30.9 & 29.7 & 30.5 & \\
\hline
\end{tabular}

AKM growth regulator had significant effect on growth of sunflower plants, particularly at the height of the stem in all investigated years. The greatest effect was observed for the plants of Odes'kyi 249 hybrid, where the fluctuation was within $9.5-24.0 \%$ by year. The smallest effect (3\%) of AKM growth regulator was observed on plants of Zubr and Forvard hybrids. 
The zone of southern steppe of Ukraine is characterized by frequent gusty winds. So, well-formed stem of sunflower plant is the main protector against lodging. We found that AKM PGR had significant effect on stem diameter in all years studied with an average of $6.4 \%$. Maximum growth regulator effect on stem diameter was observed in plants of Forvard hybrid in 2013 (13.8\%).

Under AKM effect, number of leaves per plant increased by $2-12 \%$ compared to the control. Effect of hydrothermal conditions of the year on the effectiveness of the PGR on the figure was the same for all the studied hybrids.

In our studies the leaf surface area was determined at $\mathrm{BBCH}-61-65$ (flowering) stage of plant development. Research variant exceeded the control for all investigated hybrids in average by $7 \%$ by this index. Reduction of leaf surface a trial version on $2.8 \%$ was observed in 2014 for plants of Odes'kyi 249 hybrid, and in more stress year of 2013, research version exceeded control by $6.3 \%$. Between leaf surface area and rainfall (BBCH - 00-65) a correlation of high strength was found for all hybrids $(r=0.868-0.996)$, which once again confirms the hypothesis of anti-stress (antioxidant) properties of our preparation.

Plant density in researched years was low (Tab. 4). Due to unfavorable hydrothermal conditions irregularity was observed in the arrangement of sunflower plants in the crop. The biggest difference between the control and experimental variants in plant density was marked in arid 2013. The maximum difference was observed in the crop of Forvard sunflower hybrid and was $11.4 \%$. In more humid $(2014-2015)$ years the difference between research and control variants was not significant.

In 2014, soil and air drought in the phase of inflorescence formation (BBCH - 51-53) was observed. This had a negative impact on their formation, namely diameter. The greatest stability in performance between the control and experimental variants was shown by the plants of Odes'kyi 249 hybrid, where the fluctuation was within $0.4-2.9 \%$. Overall AKM had a positive effect on the diameter of the inflorescence and increased this figure by an average of $7.3 \%$.

Table 4: Structure of sunflower yield under AKM growth regulator action depending on hydrothermal conditions of the year

\begin{tabular}{|c|c|c|c|c|c|c|c|c|c|c|}
\hline \multirow[t]{4}{*}{ Indices } & \multirow{4}{*}{ 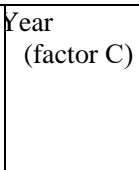 } & \multicolumn{8}{|c|}{ Hybrid (factor A) } & \multirow{4}{*}{$\begin{array}{l}\mathrm{LSD}_{05} \\
\mathrm{~A} \\
\mathrm{~B} \\
\mathrm{C}\end{array}$} \\
\hline & & \multicolumn{2}{|l|}{ Zubr } & \multicolumn{2}{|c|}{ Odes'kyi 249} & \multicolumn{2}{|c|}{ Forvard } & \multicolumn{2}{|l|}{ Yason } & \\
\hline & & \multicolumn{8}{|c|}{ GR (factor B) } & \\
\hline & & no PGR & AKM & $\begin{array}{l}\text { no } \\
\text { PGR }\end{array}$ & $\mathrm{AKM}$ & $\begin{array}{l}\text { no } \\
\text { PGR }\end{array}$ & $\mathrm{AKM}$ & no PGR & AKM & \\
\hline \multirow{3}{*}{$\begin{array}{c}\text { Plantdensity, } \\
\text { thousand units/ha }\end{array}$} & 2013 & 33.8 & 36.4 & 40.5 & 41.7 & 38.2 & 43.1 & 36.6 & 40.6 & \multirow{3}{*}{$\begin{array}{l}0.4 \\
0.2 \\
0.2\end{array}$} \\
\hline & 2014 & 43.1 & 44.4 & 42.7 & 43.1 & 42.0 & 43.9 & 44.1 & 46.0 & \\
\hline & 2015 & 43.5 & 44.8 & 42.8 & 44.5 & 41.6 & 43.6 & 44.8 & 46.5 & \\
\hline \multirow{3}{*}{$\begin{array}{l}\text { Inflorescence } \\
\text { diameter, } \\
\mathrm{cm}\end{array}$} & 2013 & 14.34 & 16.17 & 17.03 & 17.46 & 15.42 & 16.07 & 16.45 & 17.37 & \multirow{3}{*}{$\begin{array}{l}0.3 \\
0.2 \\
0.2\end{array}$} \\
\hline & 2014 & 12.09 & 13.31 & 16.12 & 16.61 & 12.23 & 13.62 & 16.42 & 16.83 & \\
\hline & 2015 & 14.89 & 16.05 & 16.63 & 16.69 & 14.61 & 17.39 & 15.37 & 18.32 & \\
\hline \multirow{3}{*}{$\begin{array}{l}\text { Seed weight in } 1 \\
\text { inflorescence, } \\
\mathrm{g}\end{array}$} & 2013 & 39.60 & 45.31 & 58.55 & 67.11 & 30.18 & 36.25 & 35.08 & 36.71 & \multirow{3}{*}{$\begin{array}{l}1.0 \\
0.7 \\
0.8 \\
\end{array}$} \\
\hline & 2014 & 37.43 & 44.79 & 54.81 & 62.13 & 25.36 & 28.81 & 31.75 & 32.08 & \\
\hline & 2015 & 40.80 & 45.94 & 58.47 & 67.37 & 27.24 & 37.19 & 33.96 & 33.67 & \\
\hline \multirow{3}{*}{$\begin{array}{l}\text { Biological yield, } \\
\text { t/ha }\end{array}$} & 2013 & 1.3 & 1.6 & 2.4 & 2.8 & 1.2 & 1.6 & 1.3 & 1.5 & \multirow{3}{*}{$\begin{array}{l}0.4 \\
0.1 \\
0.2\end{array}$} \\
\hline & 2014 & 1.6 & 2.0 & 2.3 & 2.7 & 1.1 & 1.3 & 1.4 & 1.5 & \\
\hline & 2015 & 1.8 & 2.1 & 2.5 & 3.0 & 1.1 & 1.6 & 1.5 & 1.6 & \\
\hline \multirow{3}{*}{$\begin{array}{c}\text { Rate of the genetic } \\
\text { potential of the } \\
\text { variety realization, } \\
\%\end{array}$} & 2013 & 34.2 & 42.1 & 77.4 & 90.3 & 41.4 & 55.2 & 34.2 & 39.5 & \\
\hline & 2014 & 42.1 & 52.6 & 74.2 & 87.1 & 37.9 & 44.8 & 36.8 & 39.5 & \\
\hline & 2015 & 47.4 & 55.3 & 80.6 & 96.8 & 37.9 & 55.2 & 39.5 & 42.1 & \\
\hline
\end{tabular}

PGR had an essential influence on seed weight in the inflorescence which under the influence of AKM increased by 11.2 - $26.8 \%$ compared to control for Zubr, Odes'kyi 249, and Forvard hybrids. For plants of Yason hybrid this effect was unreliable. The largest mass of seeds from 1 inflorescence was formed by plants of Odes'kyi 249 hybrid in all years researched.

Positive impact of AKM PGR on the formation of vegetative and generative organs of sunflower plants was reflected in such integrated index as biological productivity (tab. 4). The greatest influence of AKM on the yield of sunflower plants found for Zubr and Forvard hybrids, where fluctuation was within $14.3-31.3 \%$. Odes'kyi 249 hybrid has shown the greatest stability in yield over the years, where the difference between the control and experimental variants ranged within $14.3-16.7 \%$. Plants of this hybrid realized their genetic potential almost by $100 \%$. 


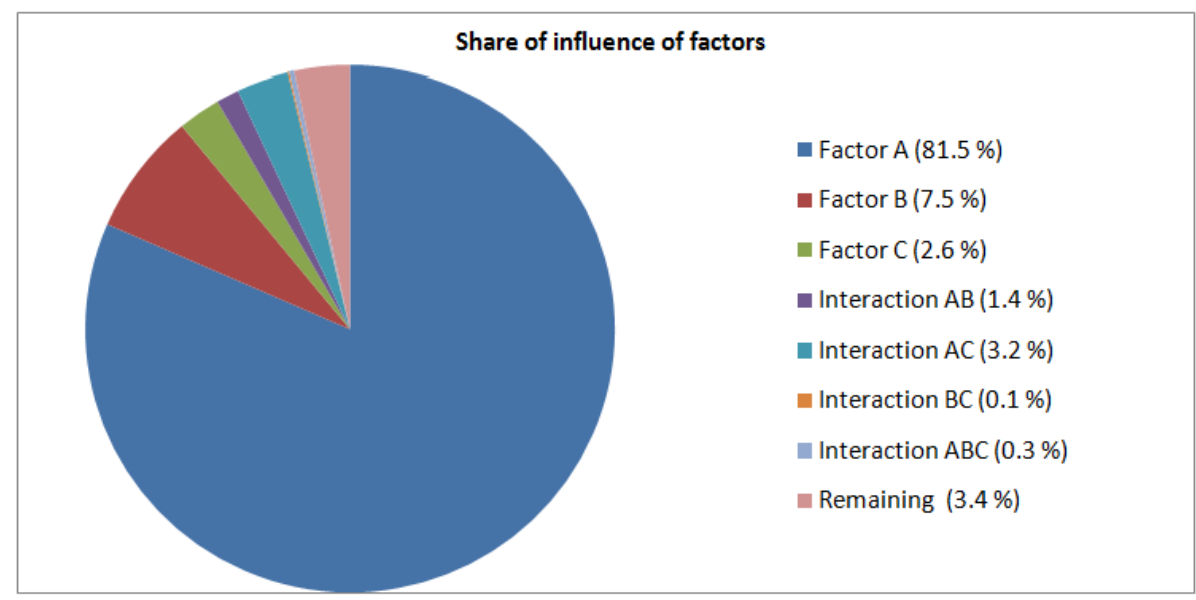

Fig. 1: The share of influence of factors on formation of sunflower yield, $\%$

In general, all researched factors affect the yield of sunflower (Fig. 1). This should be considered when developing anti-stress techniques in technologies of growing sunflowers in the Steppe zone of Ukraine.In researched years between the control and AKM application variants only a tendency to change seed desquamation was found (Table 5). In unfavorable for hydrothermal conditions years, a thicker seed shell formed.

Table 5: The quality of seeds of different sunflower hybrids under the effect of AKM plant growth regulator depending on hydrothermal conditions of the year

\begin{tabular}{|c|c|c|c|c|c|c|c|c|c|c|}
\hline \multirow[t]{4}{*}{ Indices } & \multirow{4}{*}{$\begin{array}{l}\text { Year } \\
\text { (factor C) }\end{array}$} & \multicolumn{8}{|c|}{ Hybrid (factor A) } & \multirow{4}{*}{$\begin{array}{l}\mathrm{LSD}_{05} \\
\mathrm{~A} \\
\mathrm{~B} \\
\mathrm{C}\end{array}$} \\
\hline & & Zubr & & Odes'k & 249 & Forvard & & Yason & & \\
\hline & & \multicolumn{8}{|c|}{ PGR (factor B) } & \\
\hline & & $\begin{array}{l}\text { no } \\
\text { PGR }\end{array}$ & AKM & $\begin{array}{l}\text { no } \\
\text { PGR }\end{array}$ & AKM & no PGR & $\mathrm{AKM}$ & $\begin{array}{l}\text { no } \\
\text { PGR }\end{array}$ & AKM & \\
\hline \multirow[t]{3}{*}{ pesquamation, $\%$} & 2013 & 27.46 & 25.39 & 29.41 & 27.59 & 22.84 & 21.73 & 24.51 & 25.09 & \multirow{3}{*}{$\begin{array}{l}0.2 \\
0.2 \\
0.4\end{array}$} \\
\hline & 2014 & 31.24 & 31.06 & 27.92 & 26.63 & 26.31 & 26.38 & 23.47 & 24.03 & \\
\hline & 2015 & 29.03 & 23.33 & 30.11 & 25.81 & 24.95 & 22.26 & 25.63 & 24.41 & \\
\hline \multirow[t]{3}{*}{ Empty-seed, \% } & 2013 & 4.7 & 4.9 & 3.5 & 2.4 & 6.9 & 6.1 & 5.5 & 5.1 & \multirow{3}{*}{$\begin{array}{l}1.2 \\
0.9 \\
5.7\end{array}$} \\
\hline & 2014 & 24.3 & 18.7 & 19.6 & 18.1 & 22.3 & 20.2 & 14.7 & 11.5 & \\
\hline & 2015 & 1.3 & 2.1 & 3.2 & 0.6 & 5.3 & 8.4 & 7.5 & 9.1 & \\
\hline \multirow{3}{*}{$\begin{array}{l}\text { Weight of } 1000 \\
\text { seeds, g }\end{array}$} & 2013 & 52.39 & 56.18 & 51.66 & 56.32 & 49.27 & 50.04 & 47.31 & 57.74 & \multirow{3}{*}{$\begin{array}{l}0.7 \\
0.8 \\
1.3\end{array}$} \\
\hline & 2014 & 47.52 & 52.74 & 48.41 & 53.74 & 45.39 & 45.72 & 45.14 & 46.08 & \\
\hline & 2015 & 54.18 & 60.89 & 54.98 & 60.57 & 48.85 & 51.17 & 45.72 & 58.41 & \\
\hline \multirow[t]{3}{*}{ Jrain-unit, $\mathrm{g} / \mathrm{l}$} & 2013 & 269.1 & 283.4 & 343.7 & 362.1 & 333.3 & 349.4 & 340.8 & 335.5 & \multirow{3}{*}{$\begin{array}{l}8.3 \\
7.2 \\
7.1 \\
\end{array}$} \\
\hline & 2014 & 260.7 & 271.5 & 327.9 & 345.2 & 327.7 & 330.6 & 332.1 & 321.7 & \\
\hline & 2015 & 276.6 & 308.2 & 370.1 & 383.4 & 332.2 & 351.7 & 324.3 & 332.9 & \\
\hline \multirow{3}{*}{$\begin{array}{l}\text { Oil content, } \\
\%\end{array}$} & 2013 & 47.5 & 47.9 & 45.3 & 44.9 & 47.7 & 49.1 & 47.6 & 47.8 & \multirow{3}{*}{$\begin{array}{l}0.3 \\
0.2 \\
0.7\end{array}$} \\
\hline & 2014 & 45.3 & 46.2 & 42.4 & 43.4 & 43.4 & 42.7 & 43.4 & 44.1 & \\
\hline & 2015 & 48.2 & 48.4 & 47.1 & 47.6 & 48.2 & 49.8 & 48.5 & 49.3 & \\
\hline
\end{tabular}

The highest empty-seed was observed in 2014 (Table. 5). AKM did not show a significant impact on this index. Empty-seed depends on the hydrothermal conditions of the year, namely the humidity during the flowering of plants. Thus the maximum difference $(23 \%)$ was found in Zubr hybrid in control variant. Correlation of high strength was established: $r=0.786$.

Weight of 1000 seeds depends on seed fullness and empty seed (Table 5). Under the action of AKM plant growth regulator 1000 seeds weight increased by an average of $2-14 \%$ depending on the hybrid. The maximum deviation of mass of 1000 seeds was characteristic for seeds of Yason hybrid. PGR AKM contributed to the formation of greater mass of 1000 seeds, but their genetic potential was realized by almost $90 \%$ only for plants of Zubr and Yason hybrids.

Quality of seeds is determined, above all, by the genetic characteristics of the variety or hybrid. Its value is affected by a large number of factors, but dominant are climatic conditions and growing technology. The lowest grain-unit during all research years was observed in the Zubr hybrid. AKM growth regulator increased grain unit of the seeds by $1-10 \%$.

The highest oil content in sunflower seeds was observed in 2015. Under the action of growth regulator there was a tendency to increase oil content in seeds. 


\section{Conclusions}

It was established that encrustation of sunflower seeds with AKM plant growth regulator stimulates seed germination, confirming the increase in field germination in 2013 between $2.2-8.9$ percentage points, and in $2014-2015-0.7-3.6$ pp for all the studied hybrids. AKM growth regulator causes activation of the growth process, which is particularly evident in height and diameter of the stem. The maximum increase in the height of the stem $(9.5-24.0 \%)$ was observed in plants of Odes'kyi 249 hybrid while stem diameter increased on average by $6.4 \%$ in all investigated hybrids. In general, both hybrids and plant growth regulator as researched factors significantly affect the yield of sunflower but the proportion of influence of hybrid (factor A) (85.1\%) is significantly higher than that of the impact of PGR (factor B) $(7.5 \%)$. This should be considered when developing anti-stress techniques in technologies of sunflower cultivation in the Steppe zone of Ukraine. Correlation of high strength was found between leaf surface area and rainfall (BBCH - 00-65) for all of hybrids $(\mathrm{r}=0.868-0.996)$. PGR had essential influence on seed weight in the inflorescence which under the influence of AKM increased by 11.2 - $26.8 \%$ compared to control for Zubr, Odes'kyi 249 and Forvard hybrids. AKM showed the greatest influence on the yield of sunflower plants of Zubr and Forvard hybrids, where fluctuation was within $14.3-31.3 \%$. Under the action plant growth regulator AKM 1000 seeds weight increased by an average of $2-14 \%$ depending on the hybrid.

\section{Conflict of Interests}

The authors declare that there is no conflict of interests regarding the publication of this paper.

\section{References}

[1]. I. I. Klimenko, Effect of plant growth regulators and fertilizers on seed yield of lines and sunflower hybrids, Selection and seed science, Issue 107, 2015, 183-188.

[2]. O. M. Prokopenko, Agriculture of Ukraine 2015, Statistical Yearbook, Ukraine, Kyiv, 2016, 379 p. http://www.ukrstat.gov.ua

[3]. State Register of Plant Varieties Suitable for Dissemination in Ukraine in 2015, 377 p www. http://vet.gov.ua/node/919

[4]. N. V. Markova, Influence of sowing terms and technological features of cultivation on the formation of yield and seed quality of hybrids of sunflower, Herald of agrarian science of Black sea region, Mykolayv, Issue 2 (53), 2010, 212-218.

[5]. L. F. Hernandez, Morphogenesis in sunflower (Helianthus annuus L.) as affected by exogenous application of plant growth regulators, Agriscientia, Vol. XII, 1996, 3-11.

[6]. S. Noreen, M. Ashraf, M. Hussain and A. Jamil, Exogenous application of salicylic acid enhances antioxidative capacity in salt stressed sunflower (Helianthus annuus L.) plants, Pak. J. Bot, № 41(1), 2009, 473-479.

[7]. N. V. Markova, Formation of productivity of sunflower hybrids depending on sowing terms and weed control measures in the conditions of southern Steppe of Ukraine, Herald of agrarian science of Black sea region, Issue 4, Volume 1, $2011,170-175$.

[8]. O. A. Eremenko and V. V. Kalitka, Effect of plant growth regulators on growth, development and yield formation of sunflower in the conditions of southern Steppe of Ukraine, Scientific presentations of National university of life and environmental sciences of Ukraine, \#1(58), 2016, nd.nubip.edu.ua/2016_1/13.pdf

[9]. Soil quality. Methods of determination of organic matter: DSTU [Valid from 2007-04-29], Derzhspozhivstandart of Ukraine, p. 11, 2007 (National standard of Ukraine).

[10]. O. M. Gerkial, G. M. Gospodarenko and Y. V. Kolarkov, “Agrochemistry: Study Guide,” Uman, p. $300,2008$.

[11]. Soils. Determination of mobile compounds of phosphorus and potassium using modified Chirikov method: DSTU $4115-2002$. [Valid from 2002-07-18], Derzhspozhivstandart of Ukraine, p. 13, 2002. (National standard of Ukraine).

[12]. Oil seeds. Determination of oil by extraction method in Soxhlet device: DSTU 7577:2014. [Valid from 2014-10-11], Derzhspozhivstandart of Ukraine, p. 10, 2015. (National standard of Ukraine).

[13]. Soil quality. Indices of soil fertility: DSTU 4362:2004. [Valid from 2006 - 01 - 01], Derzhspozhivstandart of Ukraine, p. 19 , 2006.

[14]. D. M. Brown and A. Bootsma, "Crop Heat Units for Corn and Other Warm Season Crops in Ontario" Factsheet Ministry of Agriculture, Food and Rural Affairs, 1993, $32-41$.

[15]. V. V. Kalytka, Z. V. Zolotuhina, O. A. Ivanchenko, T. M. Yaloha and O. I. Zhernovy, "Anti-stress composition for pre-sowing seed treatment of agricultural crops," Patent. 58260 Ukraine, MPK ${ }^{51}$ A01C 1/06, A01N 31/00. №201010482; publ. 11.04.2011, Bull. №7.

[16]. Methodology of field experiments for the study of agronomical sunflower cultivation measures, Methodical recommendations. Zaporizhzhya, p.16, 2005.

[17]. V. S. Pustovoyt, "Selected works," Agropromizdat, p. 368, 1990.

[18]. P. S. Popov and V. N. Kozhevnikova, "Quality of seeds in the zones of sunflower basket," Journal of Oilseed industry, vol. 3, 1981, $9-12$,

[19]. B. A. Dospekhov, "Methods of field experiment (with the fundamentals of statistical processing of the results of research)," Agropromizdat, p. 351, 1985.

[20]. M. G. Nikolaeva and N. V. Obrucheva, "Physiology and biochemistry of dormancy and germination of seeds," [Transl. from English by N. A. Askochevska, N. A. Gumilevska, E. P. Zavertkina, E. E. Havkin], Kolos, p. 495, 1982.

[21]. V. V. Kalytka, Z. V. Zolotuhina, Produktivnost pshenicy ozimoj za predposevnoj obrabotki semyan antistressovoj kompoziciej, Scientific herald of National university of life and environmental sciences of Ukraine, Vol. 162: Series: «Agronomy», 2012, 93 99.

[22]. L. A. Pokoptseva, O. A. Eremenko and D. V. Bulgakov, The use of plant growth regulators for pre-sowing treatment of sunflower seeds of Armada hybrid, Herald of agrarian science of Black sea region, Issue 4 (87), 2015, 127-136. 